\title{
An experimental test of rainfall as a control agent of Glycaspis brimblecombei Moore (Hemiptera, Psyllidae) on seedlings of Eucalyptus camaldulensis Dehn (Myrtaceae)
}

\author{
Karla N. Oliveira ${ }^{1}$, Fabiene M. de Jesus ${ }^{1}$, Jhonathan O. Silva ${ }^{1}$, Mário M. do Espírito-Santo ${ }^{1}$ \& Maurício L. Faria ${ }^{1}$
}

${ }^{1}$ Laboratório de Ecologia Evolutiva, Centro de Ciências Biológicas e da Saúde, Departamento de Biologia Geral, Universidade Estadual de Montes Claros, Campus Universitário Prof. Darcy Ribeiro. Caixa Postal 126, 39401-089 Montes Claros-MG, Brasil. karlanunesbio@gmail.com; bienebio@yahoo.com.br; jhonathanos@gmail.com; mario.marcos@unimontes.br; mauricio.faria@unimontes.br

\begin{abstract}
An experimental test of rainfall as a control agent of Glycaspis brimblecombei Moore (Hemiptera, Psyllidae) on seedlings of Eucalyptus camaldulensis Dehn (Myrtaceae). Glycaspis brimblecombei is one the greatest threats to eucalyptus plantations in Brazil. The effects of rainfall to reduce the abundance of lerp of Glycaspis brimblecombei on experimentally infested seedlings of Eucalyptus camaldulensis were assessed. The number of lerps on the adaxial and abaxial surfaces of every leaf of 60 seedlings was recorded, before and after submission to the following treatments: "artificial rain", "leaf wetting" and control. A drastic reduction in lerp abundance per plant was observed after the treatments "leaf wetting" and artificial rain $(\mathrm{F}=53.630 ; \mathrm{p}<$ $0.001)$, whereas lerp abundance remained roughly constant in the control treatment along the experiment $(F=1.450 ; p=0.232)$. At the end of the experiment, lerp abundance was significantly lower in both the "artificial rain" and "leaf wetting" than in the control treatment. Two days of rainfall simulation were sufficient to decrease more than $50 \%$ of the lerp population, with almost $100 \%$ of effectiveness after 5 days of experiment. Our results indicate that lerp solubilization and mechanical removal by water are potential tools to the population regulation of G. brimblecombei on E. camaldulensis seedlings.
\end{abstract}

KEYWORDS. Herbivory; pest management; red gum lerp psyllid.

RESUMO. Teste experimental da chuva como agente de controle de Glycaspis brimblecombei Moore (Hemiptera, Psyllidae) em mudas de Eucalyptus camaldulensis Dehn (Myrtaceae). Glycaspis brimblecombei é uma das maiores ameaças das plantações de eucalipto do Brasil. Foram avaliados os efeitos da água na redução da abundância de conchas desse inseto em mudas de Eucalyptus camaldulensis infestadas experimentalmente. Foi quantificado o número de conchas nas superfícies adaxial e abaxial de todas as folhas de 60 mudas, antes e após a aplicação dos seguintes tratamentos: "chuva artificial", "molhamento das folhas" e controle. Foi observada uma drástica redução na abundância de conchas nos tratamentos "chuva artificial" e "molhamento das folhas" ( $F=53,630$; $\mathrm{p}<0,001)$, o que não ocorreu para o tratamento controle ao longo do experimento $(\mathrm{F}=1,450 ; \mathrm{p}=0,232)$. Ao final do experimento, a abundância de conchas foi significativamente menor no tratamento "chuva artificial" e "molhamento das folhas" do que no tratamento controle. Dessa forma, dois dias de chuva mostraram ser eficientes para diminuir mais que $50 \%$ da população de conchas, com quase $100 \%$ de eficiência após 5 dias de experimento. Nossos resultados indicam que a solubilização das conchas e a remoção mecânica pela água são potenciais ferramentas para regulação populacional de G. brimblecombei em mudas de E. camaldulensis

PALAVRAS-CHAVE. Herbivoria; manejo de pragas; psilídeo-de-concha.

The red gum lerp psyllid, Glycaspis brimblecombei Moore 1964 (Hemiptera, Psyllidae) has currently become one of the major threats of eucalyptus plantations worldwide. This insect is native from Australia and was accidentally introduced in the United States (Brennan et al. 1999), Mexico (Sanchez 2003), Argentina (Diodato \& Venturini 2007), Mauritius Islands (Paine \& Dreistadt 2007) and recently in Portugal and Spain (Valente \& Hodkinson 2009), causing significant economic losses in eucalyptus plantations. In Brazil, $G$. brimblecombei was first reported in the state of São Paulo in 2003 (Santana \& Burckhardt 2007) and its occurrence is now reported in 10 states, being considered the major threat to silviculture in the country (Wilcken et al. 2003; Lutinski et al. 2006; Oliveira et al. 2006; Silva et al. 2010). Since Brazil possesses the largest eucalyptus planted forest in the world, covering more than 3 million hectares (Santos et al. 2002; Ministério da Ciência e Tecnologia 2006), effective control- ling efforts urge to avoid negative consequences to the production of charcoal, cellulose and wood, with severe losses to Brazilian economy.

Glycaspis brimblecombei reproduces sexually and females usually oviposit from 6 to 45 eggs per leaf, preferentially on new leaves. Egg development ranges between 7 to 9 days and, after the eclosion, nymphs establish preferably next to the leaf veins (Firmino-Winckler et al. 2009). After the initial feeding, the nymph eliminates honeydew, which is used, together with wax secretion, to build a tapered-shape white shelter (lerp) (Halbert et al. 2001). The lerps of $G$. brimblecombei nymphs are loosely fixed to the leaf surface and are often abandoned by the nymphs as they seek new feeding sites. Previous studies observed that the lerp is large enough such that the psyllid nymph can move within the lerp in order to avoid natural enemies (Sullivan et al. 2006). The complete life cycle varies from 15 to 34 days, with several 
generations per year (Firmino-Winckler et al. 2009). At higher densities, the harmful effects of this insect on infested eucalyptus are pronounced, causing high defoliation rates, death of the apical meristem or even plant death (Wilcken et al. 2003). The attack of $G$. brimblecombei is more intense on Eucalyptus camaldulensis Dehn 1832 (river red gum) and Eucalyptus tereticornis Smith 1795 (Paine et al. 2000; Brennan et al. 2001), but the attack on E. urophylla Blake 1977 and on hybrid clones of E. grandis x urophylla was also registered in Brazil (Wilcken et al. 2003; FirminoWinckler et al. 2009, Silva et al. 2010).

Previous studies recorded an attack peak predominantly during dry months (Ramirez et al. 2003), which makes important to control G. brimblecombei populations during this period. Also, a previous study conducted with E. camaldulensis in the north of Minas Gerais (K. N. Oliveira, unpublished data) detected a much higher average density of $G$. brimblecombei lerps during the dry season $\left(0.201 \mathrm{lerps} / \mathrm{cm}^{2} \pm 0.052\right) \mathrm{com}-$ pared to the rainy months $\left(0.012\right.$ lerps $\left./ \mathrm{cm}^{2} \pm 0.007\right)$ along one year. One of the methods used to control the red gum lerp psyllid is the application of chemical pesticides, but this strategy is expensive, harmful to man and the environment, and provides only a temporary solution (Santana \& Burckhardt 2007). The biological control of this pest was considered a viable option (Daane et al. 2005; Sullivan et al. 2006), and the exotic specialist parasitoid Psyllaephagus bliteus Riek 1962 (Hymenoptera: Encyrtidae) have already been recorded in Brazilian Eucalyptus plantations. This natural enemy was recorded in 2003 in São Paulo state together with its host $G$. brimblecombei (Wilcken et al. 2003). During the last decade, $P$. bliteus has been successfully created under laboratory conditions in Brazil and released in Eucalyptus plantations for biological control purposes. However, the parasitism rates of G. brimblecombei nymphs by P. bliteus under field conditions at northern Minas Gerais state are still low (Jesus 2009), suggesting that this parasitoid might not be adapted to the environmental conditions of this region.

Glycaspis brimblecombei should be preferably controlled by a programme of pest integrated management (IPM), considering the interactions of this insect with the environment and other organisms (Santana \& Burckhardt 2007). There is evidence that rain is a potential control agent of this psyllid, since previous studies showed a reduced attack of $G$. brimblecombei on Eucalyptus plantations during the wet season of the year (Ramirez et al. 2003; Wilcken et al. 2003). It is common to observe many lerps on the ground in a Eucalyptus plantation after heavy rains (K.N. Oliveira, pers. obs.), suggesting a mechanical lerp removal from the host leaves. Also, leaf wetting by rain may affect lerp structure, causing its dissolution and detachment from leaf surface. In this study, we used an experimental approach to test the following hypotheses regarding the effects of rain on G. brimblecombei: (i) raindrops mechanically remove the lerps from Eucalyptus leaves; ii) leaf wetting can decrease lerp adhesion capacity on wet leaves; and (iii) Lerp mechanical removal by raindrops is more intense for nymphs installed on adaxial than on abaxial leaf surfaces.

\section{MATERIAL AND METHODS}

The experiment was performed in a greenhouse at Universidade Estadual de Montes Claros (Unimontes), Brazil, between July and August 2007 (middle of the dry season), when no precipitation was recorded and the average temperature was $20.05^{\circ} \mathrm{C}$ (data from Unimontes Meteorological Station). Sixty seedlings of $E$. camaldulensis were randomly selected from the Vallourec and Mannesman S.A clonal garden at Olhos D'água, Minas Gerais state. These seedlings were produced by serial vegetative propagation (minicuttings), where $E$. camaldulensis sprouts were cut and rooted into a solid cultivation substrate inside greenhouses at Fazenda Extrema in Olhos D’água $\left(17^{\circ} 15 \mathrm{~S}, 43^{\circ} 39 \mathrm{~W}\right)$. After 2 months of development, the seedlings were transferred to a climate-controlled room at the Laboratório de Ecologia Evolutiva at Unimontes, with temperature of $22 \pm 3^{\circ} \mathrm{C}, 60 \%$ of air humidity and a $12: 12$ photoperiod. In this room, the seedlings were divided into four cages, with 15 plant placed into each cage and watered daily with 250 $\mathrm{ml}$ each plant. Adults of Glycaspis brimblecombei collected in heavily attacked plantations of E. camaldulensis at Fazenda Extrema were taken to the laboratory at Unimontes and 200 adults insects were released per cage, regardless of their sex. After 3 weeks, plant leaves were heavily infested with psyllid lerps and ready to start the experiment. Each seedling had 15 leaves in average, and some leaves frequently showed a reversed orientation, with the abaxial surface turned up.

We performed an experimental design with three treatments with 20 seedlings each: "artificial rain", "leaf wetting" and control. These 60 seedlings were submitted to these treatments for five consecutive days, and lerps were counted daily on both surfaces of all leaves on each seedling. After a 10 -day interval, the treatments were again applied to the same 60 seedlings for other five consecutive days. During the 10day interval, nymphs of G. brimblecombei were able to recolonize the seedlings from which their lerps were experimentally removed. The entire experiment was conducted during 20 consecutive days.

In the "artificial rain" treatment, seedlings were exposed to water from a garden sprinkler positioned at two meters in height inside the greenhouse, during two non-consecutive hours per day: one hour in the morning (08:00-09:00 am) and one hour in the afternoon (03:00-04:00 pm). In the "leaf wetting" treatment, we sprayed $200 \mathrm{~mL}$ of water on the seedling leaves every 15 minutes of experiment (4 times in the morning and 4 times in the afternoon, at the same time of the "artificial rain" treatment), totalling $1600 \mathrm{~mL}$ per day $(200 \mathrm{~mL}$ x 8). Thus, these treatments aimed to evaluate two possible additive effects of rain on $G$. brimblecombei lerps: the effects of lerp solubilization alone were accessed in the "leaf wetting" treatment, since the water was gently applied with a manual trigger pulveriser. In the "artificial rain" treatment, in addition to leaf wetting, we also evaluated the impact of lerp mechanical removal by water droplets.

In both treatments, we placed a polystyrene container $(9.5 \mathrm{~cm}$ in height and $7 \mathrm{~cm}$ in radius, the same dimensions of 
the pots where the seedlings were planted) next to the plants to measure the volume of water poured inside plant pots during each water application. In the "leaf wetting" treatment, the average volume added to the plants per day of experiment was $0.886 \pm 0.077 \mathrm{~mm}$, whereas in the "artificial rain" treatment, this volume reached $29.297 \pm 1.908 \mathrm{~mm}$. The average annual rainfall for the original region of the psyllids used in this experiment (Olhos D'Água) is $1065 \mathrm{~mm}$. Thus, the amount of water added in the "artificial rain" treatment simulates a short period of intense rainfall (approximately $60 \mathrm{~mm}$ of rain per day), which is eventually recorded in Fazenda Extrema during the rainy season (data from the Fazenda Extrema meteorological station). In the control treatment, the seedlings did not receive water directly on their leaves to avoid contact with the lerp. To equalize the level of water received by all 60 seedlings, the plants of the "leaf wetting" and control treatments were watered daily directly on the roots. This procedure was conducted to avoid possible effects of water stress in relation to the artificial rain treatment, which could cause differences on $G$. brimblecombei performance between treatments.

To verify the effects of the treatments and time on lerp abundance, we adjusted linear mixed-effects model (LME) (Crawley 2002). The data were collected repeatedly in the same 60 plants along ten non-consecutive days of experiment (two repetitions). The temporal autocorrelation generated by sampling the same plants in subsequent dates violates the assumption of independence of the samples. The use of mixed models is recommended to deal with the structure of correlated errors in this type of sampling design (Crawley 2002). Thus, the data were grouped per plant and the variances of errors calculated for each different individual along time. In this case, the response is not the individual measure, but the sequence of measures in an individual (Crawley 2002). These analyses were conducted with the software R 2.6.2 (R Development Core Team 2008).

\section{RESULTS}

Plants assorted into the three treatments did not show statistical differences in lerp abundance before the experiment ( $F$ $=0.727, \mathrm{p}=0.4834$; Fig. 1). After the experiment, the mean lerp abundance was significantly lower on plants of the "artificial rain" treatment compared to "leaf wetting" and control treatments; plants from the "leaf wetting" treatment also presented a significantly lower lerp abundance than control plants (constrast analysis; $\mathrm{F}=88.05, \mathrm{p}=0.01$; Fig. 1). The mean lerp abundance per plant decreased significantly along the five days of experiment $(\mathrm{F}=53.63, \mathrm{p}<0.001)$ for "leaf wetting" and "artificial rain" treatments, though the nymphs were able to resettle and rebuild the lerp even between the morning and afternoon water applications during the first days of experiment. In both treatments, we directly observed lerp melting on wet leaves. In the "artificial rain" treatment, we also observed a large number of lerps on the ground beneath the seedlings.

The "leaf wetting" treatment showed a high reduction on lerp abundance after the first two days of experiment, about
$56 \%$ (Fig. 1), followed by a reduction of $32 \%$ of the remaining lerps from the second to the fifth day of experiment $(\mathrm{F}=$ 30.712 , $p<0.001$; Fig. 1). The same pattern was observed for the artificial rain treatment, where approximately $88 \%$ of the lerps were removed after the first two days of experiment (Fig. 1), followed of removal of $63 \%$ of the remaining lerps from the second to the fifth day of experiment $(\mathrm{F}=$ $47.712, \mathrm{p}<0.001$; Fig. 1). As a whole, after 5 days of experiment (considering the average value from two repetitions), $70 \%$ and $96 \%$ of the lerps were removed in the "leaf wetting" and "artificial rain" treatments, respectively. In contrast, no significant differences in lerp abundance were observed in the control treatment along the experiment $(\mathrm{F}=$ $1.450, \mathrm{p}=0.232$; Fig. 1). Thus, two days of experiment were sufficient to drastically reduce the lerp abundance of $G$. brimblecombei on the seedlings of E. camaldulensis. There were no differences in the abundance of G. brimblecombei lerps between leaf surfaces for any treatment, before or after the experiment (Table I).

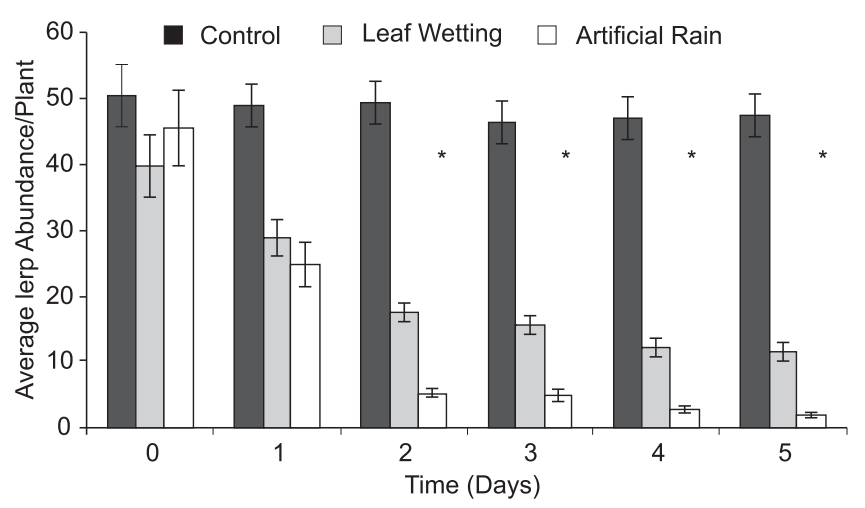

Fig.1. Abundance of G. brimblecombei lerps on E. camaldulensis along a five-day experiment with the following treatments: Control, Leaf Wetting and Artificial Rain $(1 \pm \mathrm{SE} ; \mathrm{N}=20$ seedlings per treatment). Data were pooled for the two five-day experiment repetitions. Asterisks (*) above bars indicate days when significant differences among all treatments were detected.

Table I. Comparison of $G$. brimblecombei lerp abundance between adaxial and abaxial leaf surfaces of $E$. camaldulensis seedlings, before and after three different treatments: Control, Leaf Wetting and Artificial Rain. N = 20 seedlings per treatment, $n . s=$ non significant at $0.05 \mathrm{P}$ level. Data were pooled for the two five-day experiment repetitions. $\mathrm{F}$ and $\mathrm{P}$ values refer to leaf surface comparisons only.

\begin{tabular}{lcccc}
\hline & \multicolumn{2}{c}{ Surface } & \multirow{2}{*}{ F } & P \\
\cline { 2 - 3 } & Adaxial & Abaxial & & \\
\hline Before treatments & & & & \\
Control & $55.7 \pm 7.76$ & $45.43 \pm 5.72$ & 1.833 & 0.192 n.s \\
Leaf Wetting & $35.4 \pm 5.15$ & $44.0 \pm 7.97$ & 0.948 & 0.343 n.s \\
Artificial Rain & $45.8 \pm 9.42$ & $45.1 \pm 6.97$ & 0.007 & 0.936 n.s \\
After treatments & & & & \\
Control & $47.4 \pm 7.07$ & $45.6 \pm 5.90$ & 0.059 & 0.811 n.s \\
Leaf Wetting & $11.9 \pm 2.96$ & $10.3 \pm 2.30$ & 0.347 & 0.563 n.s \\
Artificial Rain & $1.4 \pm 0.511$ & $1.0 \pm 0.46$ & 0.357 & 0.558 n.s \\
\hline
\end{tabular}




\section{DISCUSSION}

This study was the first to experimentally show that the rain has regulatory effects on $G$. brimblecombei populations, with an effectiveness of up to $96 \%$ (Fig. 1). These results corroborate those obtained by Ramirez et al. (2003), who observed that frequent rains contributed to lerp fall, causing a populational decline of the red gum lerp psyllid. According to our results and observations, rainfall has two synergistic effects on G. brimblecombei. The first is the effect of leaf wetting, which can lead to the solubilization of the lerp sugars, exposing the nymphs to adverse environmental conditions or predator attack. This proposition is supported by the reduction of the lerp abundance in the "leaf wetting" treatment and direct observations of lerp melting. Furthermore, the increase in humidity may have slower, indirect effects on nymphs, since it can facilitate the occurrence of entomopathogenic fungi. In fact, Favaro (2006) showed that much of the reduction of this insect population during the rainy season is due to the action of microorganisms.

The second effect of the rain is the mechanical removal of the lerps by the impact of water droplets, indicated by the drastic reduction on lerp abundance in the artificial rain treatment. The greater effectiveness of this treatment in relation to the "leaf wetting" treatment suggests that mechanical removal may be facilitated by solubilization provided by leaf moisture. Thus, the direct action of raindrops on the leaves of E. camaldulensis is also an important factor in the populational control of red gum lerp psyllid. Nevertheless, more detailed studies are needed to determine the indirect effects of the increased water availability on $G$. brimblecombei via changes in host plant quality. It is possible that the greater water availability for individuals of $E$. camaldulensis during the rainy season increases the concentration of chemical defenses or decreases the nutrient content in the plant sap, with negative consequences to population of the red gum lerp psyllid.

The nymph installation and lerp production on leaf abaxial surface did not provide any kind of protection against the impact of raindrops in the present experiment. According to Strong et al. (1984), low-mobility herbivorous insects would avoid adverse environmental conditions by choosing to feed on the leaf abaxial surface, where the risk of removal by wind and rain is reduced. In this study, we observed that the leaves of the seedlings used in experiment had, in many cases, a reversed orientation, with the abaxial surface turned up. It is possible that this peculiarity had some influence in the lack of differences in the lerp abundance between leaf surfaces observed in here.

The use of water certainly has many methodological limitations in large plantation areas, with potentially high costs. Moreover, the collection and addition of large amounts of water in these plantations would cause other environmental impacts common to any large-scale irrigation system, such as soil leaching and depletion of natural water resources, not to mention the unpredictable consequences for the surrounding native flora and fauna. It is likely that the best way to use the water effects in an environment friendly control of the red gum lerp psyllid is landscape management, plantation of seedlings at the beginning of the rainy season, and the maintenance of native vegetation remnants which can retain moisture at the plantation edges.

\section{ACKNOWLEDGEMENTS}

We thank the Vallourec \& Mannesman S.A for the logistical support, in special to Josefredo Dias Moreira, Vilmar de Assis Izidoro and Bianca Vique Fernandes. We also thank Herbert S. Silva, William Bandeira, Juliana Tuller and Luma N. Oliveira for the help during the experiment. This study was supported by Fundação de Amparo à Pesquisa de Minas Gerais-FAPEMIG (Process EDT-318/05). The authors greatly acknowledge the scholarships to Karla Nunes Oliveira (Probic-FAPEMIG), Jhonathan de Oliveira Silva (Bic-UNIMONTES) and Mário Marcos do Espírito-Santo (BIPDT-FAPEMIG).

\section{REFERENCES}

Brennan, E. B.; R. J. Gill; G. F. Hrusa \& S. A. Weinbaum. 1999. First record of Glycaspis brimblecombei (Moore) (Homoptera: Psyllidae) in North America: initial observations and predator associations of a potentially serious new pest of Eucalyptus in California. The Pan-Pacific Entomologist 75:55-57.

Brennan, E. B.; G. F. Hrusa; S. A. Weinbaum \& W. Levison Jr. 2001. Resistance of Eucalyptus species to Glycaspis brimblecombei (Homoptera: Psillidae) in the San Francisco by area. The Pan-Pacific Entomologist 77: 249-253.

Crawley, M. J. 2002. Statistical computing: An introduction to data analysis using S-Plus. Baffins Lane, John Wiley \& Sons, ix+761 p.

Daane, K. M.; K. R. Sime; D. L. Dahlsten; J. W. Andrews Jr \& R. L. Zuparko. 2005. The biology of Psyllaephagus bliteus Riek (Hymenoptera: Encyrtidae), a parasitoid of the red gum lerp psyllid (Hemiptera: Psylloidea). Biological Control 32: 228-235.

Diodato, L. \& M. Venturini. 2007. Presencia del "psílido del escudo" (Glycaspis brimblecombei, Hemiptera, Psyllidae), plaga del Eucalyptus, en Santiago del Estero, Argentina. Quebracho 14: 84-89.

Favaro, M. R. 2006. Aspectos bionômicos de Glycaspis brimblecombei (Moore,1964) (Hemiptera: Psyllidae) e seu controle com fungos entomopatogênicos. Dissertation, Curitiba,Universidade Federal do Paraná, 43 p.

Firmino-Winckler, D. C.; C. F. Wilcken; N. C. de Oliveira \& C. A. O. de Matos. 2009. Biologia do psilídeo-de-concha Glycaspis brimblecombei Moore (Hemiptera, Psyllidae) em Eucalyptus spp. Revista Brasileira de Entomologia 53: 144-146.

Halbert, S. E.; R. J. Gill \& J. N. Nisson. 2001. Two Eucalyptus psyllids new to Florida (Homoptera: Psyllidae). Entomology Circular 407: 1-2.

Jesus, F. M. 2009. Efeito do Estresse Hídrico na Qualidade Nutricional de Eucalyptus camaldulensis Dehn (Myrtaceae) e no Ataque de Glycaspis brimblecombei Moore (Hemiptera: Psyllidae). Dissertation, Montes Claros, Universidade Estadual de Montes Claros, 56 p.

Lutinski, J. A; C. J. Lutinski \& F. R. M. Garcia. 2006. Primeiro registro de Glycaspis brimblecombei Moore 1964, (Hemiptera: Psyllidae) em eucalipto no estado de Santa Catarina, Brasil. Ciência Rural 36: 653-655.

Ministério da Ciência e Tecnologia. 2006. Projeto Genolyptus. Available at: http://www.mct.gov.br (accessed 14 April 2006).

Oliveira, L. da S.; E. C. Costa; M. Grellmann; E. B. Cantarelli \& E. R. Perrando. 2006. Ocorrência de Glycaspis brimblecombei (Moore, 1964) (Hemiptera: Psyllidae) em Eucalyptus spp. no Rio Grande do Sul, Brasil. Ciência Florestal 16: 353-355.

Paine, T. D.; D. L. Dahlsten; J. G. Millar; M. S. Hoddle \& L. M. Hanks. 2000. UC scientists apply IPM techniques to new eucalyptus pests. California Agriculture 54: 8-13. 
Paine, T. D. \& S. H. Dreistadt. 2007. Pest notes: psyllids. Agricultural and Natural Resources Publications 7423: 1-6. Available at: http:// www.ipm.ucdavis.edu/PDF/PESTNOTES/pnpsyllids.pdf (accessed 14 October 2008).

R Development Core Team. 2008. R: A language and environment for statistical computing. R Foundation for Statistical Computing, Vienna, Austria. Available at: http://www.R-project.org. (accessed 18 May 2008).

Ramirez, A. L. G.; G. M. Mancera \& J. J. Guerra-Santos. 2003. Análisis del efecto de las condiciones ambientales en la fluctuación poblacional del psílido del eucalipto en el Estado de México. Habana. Available at: http://www.met.inf.cu/Memorias/paginas/Articulos/Extranjeros. (accessed 18 October 2006).

Sánchez, B. S. 2003. Aspectos bionómicos del psilídeo del eucalipto Glycaspis brimbecombei Moore (Homoptera: Psylloidea: Spondyliaspididae). Dissertation. Texcoco, Universidad Autónoma Chapingo, Edo. de México, $76 \mathrm{p}$.

Santana, D. L. de Q. \& D. Burckhardt. 2007. Introduced Eucalyptus psyllids in Brazil. Journal of Forest Research 12: 337-344.

Santos, G. P.; T. V. Zanuncio; E. Vinha \& J. C. Zanuncio. 2002. Influência de faixas de vegetação nativa em povoamentos de Eucalyptus cloeziana sobre população de Oxydia vesulia (Lepidoptera: Geometridae). Revista Árvore 26: 499-504.

Silva, J. O.; K. N. Oliveira; K. J. Santos; M. M. Espírito-Santo; F. S. Neves \& M. L. Faria. 2010. Efeito da Estrutura da Paisagem e do Genótipo de Eucalyptus na Abundância e Controle Biológico de Glycaspis brimblecombei Moore (Hemiptera: Psyllidae). Neotropical Entomology 39: 91-96.

Strong, D. R.; J. H. Lawton \& R. Southwood. 1984. Insects on Plants: Community Patterns and Mechanisms. Oxford, Blackwell Scientific Publications, vi, 313p.

Sullivan, D. J; K. M. Daane; K. R. Sime \& J. W. Andrews Jr. 2006. Protective mechanisms for pupae of Psyllaephagus bliteus Riek (Hymenoptera: Encyrtidae), a parasitoid of the red gum lerp psyllid, Glycaspis brimblecombei Moore (Hemiptera: Psylloidea). Australian Journal of Entomology 45: 101-105.

Valente, C. \& I. Hodkinson. 2009. First record of the Red Gum Lerp Psyllid, Glycaspis brimblecombei Moore (Hem.: Psyllidae) in Europe. Journal of Applied Entomology 133: 315-317.

Wilcken, C. F.; E. B. do Couto; C. Orlato; P. J. Ferreira-Filho \& D. C. Firmino. 2003. Ocorrência do psilídeo-de-concha (Glycaspis brimblecombei) (Hemiptera: Psyllidae) em florestas de eucalipto do Brasil. Circular Técnica - IPEF 201: 1-11. 